\title{
‘̌qēdōt \\ The binding of Isaac in early modern Polish-Lithuanian Karaite poetry
}

RIIKKA TUORI

This article deals with early modern Polish-Lithuanian Karaite poems which are based on the bib-
lical narrative of the binding of Isaac (Gen. 22). These liturgical poems ( ăqēdōt) were recited
during the ten days between the New Year and the Day of Atonement, known in Karaite tradition
as the ten days of mercy. Their main function is to express the frame of mind of the congregants
during this yearly period of repentance, eventually culminating in the sounding of the Shofar on the
Day of Atonement. The article demonstrates that the Polish-Lithuanian Karaite poets do not only
draw from the biblical narrative but rewrite it by using later midrashic and medieval interpretations
of the binding of Isaac.

In this article I will offer a first introduction to a group of Karaite Hebrew poems ('ăqèdōt, Heb. 'bindings') which deal with the biblical narrative of the binding of Isaac (Gen. 22:I-I9). The poems had a special function in Karaite religious observance: they were recited during the ten-day period of repentance extending from the first day of the month of Tishri until the Day of Atonement. The corpus contains eleven 'ăqèdōt by seven seventeenth- to eighteenth-century Polish-Lithuanian Karaite authors, and all of them are published in the Lithuanian Karaite prayer book (Siddūr ha-těfillōt kè-minhag ha-qārà̀̀m, Vilna, I 890-2)..$^{1}$ I will discuss the position of these Karaite poems in the wider context of Jewish liturgical poetry, as well as study their relationship to later Jewish re-interpretations of the biblical narrative.

\section{Karaite Judaism and the Karaites of Eastern Europe}

Karaite Judaism represents an alternative version of Judaism. Its origins lie in ninth-century Iraq (Babylonia), where the interpretation of central Jewish

1 The Karaite Siddur contains four volumes, edited by Felix (Pinehas) Malecki. On the printing of Karaite prayer books in nineteenth-century Eastern Europe, see Miller I993. 
writings became an object of dispute. In the midst of divergent opinions on who has the ultimate authority in halakhic decisions, the early Karaite ${ }^{2}$ movement rejected rabbinic tradition (Mishna and Talmud) as the divinely ordained oral Torah and promoted the right of each intellectually skilled individual to interpret the scriptures. ${ }^{3}$

Karaite Judaism - like its sister strand, rabbinic (or 'normative') Judaism - developed into a multifaceted movement that defies simple descriptions. During the first centuries of its existence, Karaism represented a competing alternative to rabbinic Judaism. Karaites engaged in intra-Jewish missionary activity, and small Karaite communities sprang up as far as Spain in the west and, by the late fourteenth century, even Lithuania in the north. In the course of time the Karaite movement crystallized into three subgroups, each with its own distinct history and language: Arabic-speaking Karaites in Iraq, Palestine, and Egypt; Greek- and later Turkish-speaking Byzantine and Turkish Karaites; and Karaites in the Crimea, Poland, and Lithuania, who employed a Turkic vernacular language, Karaim. ${ }^{4}$

Medieval Jewish texts are, for the most part, written by male authors of the elite. Women or otherwise marginalized groups rarely use their own voice in sources available to us. Karaite Jews, for example, appear in rabbinic Jewish texts as feared enemies or as derided renegades. ${ }^{5}$ Even today, Karaites are offhandedly addressed as 'heretics' or 'sectarians'. Because these terms evoke negative images, I have opted to use less loaded terms: in this article, as elsewhere, I refer to the Karaites as a 'movement', or, simply, as a 'group'. 6 Then again, the problem has never been the absence of a Karaite voice in medieval and pre-modern sources.

2 The origin of the word 'Karaite' (Heb. qārāâ) is most likely to be found in the Hebrew root $q r$ ', 'to read', referring to their 'return' to the biblical scriptures (miqräot); on the origins of the name and alternative interpretations, see Gil 2003: ro9; Polliack 2002: 3I3.

3 For the origins, history, exegetics, and philosophy of Karaite Judaism, see the wideranging articles collected in Karaite Judaism: A Guide to its History and Literary Studies, edited by Polliack (2003); for Karaite practice and customs (including modern Karaism), see Yaron and Qanaï 2003.

4 The Karaim language belongs to the north-western Kipchak group of Turkic languages and is closely related to the Tatar languages. How and where a group of medieval Karaites acquired the Karaim language remains a mystery; see, e.g., Shapira 2003, Jankowski 2003 .

5 On Karaites as the 'Other' of Judaism, see Lasker $200 \mathrm{I}$.

6 On the problematic terms 'sect', 'sectarian', 'schismatic', and 'heretic' and their history in Karaite Judaism, contra 'normative', or 'mainstream' rabbinic Judaism, see, e.g., Rustow 20I I; Cohen 2006: I I9-3 I. 
Medieval Karaites in the Middle East and in the Byzantine Empire composed a vast selection of exegetical and linguistic works, including rhymed works and liturgical poetry. In recent years a myriad of these Hebrew and Arabic texts have been published in critical editions. ${ }^{7}$ Eastern European Karaites and their multilingual works are also gradually attracting more and more interest. ${ }^{8}$

The Karaites of Eastern Europe form a distinct group of their own, with their distinctive vernacular language (the Turkic Karaim) and centuries-long habitation of the northern areas of Europe. In terms of numbers this cluster of Karaism was always minuscule: at its peak, before the nineteenth century, only a few thousand Karaites lived in Eastern Europe (Akhiezer and Shapira 200I: 2 I). ${ }^{9}$ In the Polish-Lithuanian Commonwealth (I 569-1 795), Karaites lived in three major areas: Lithuania (especially Troki and neighbouring towns), Galicia (Halicz and Kukizów), and Volhynia (Euck and Derażne). Like their other Karaite brethren, Eastern European Karaites employed Hebrew as the primary language in their scholarly and religious works, and it was also the language of administration and commerce. Polish-Lithuanian Karaite literary culture experienced a cultural and literary renaissance during the early modern period: archives in Lithuania and Russia contain plenty of religious literature, philosophical treatises, private letters, proceedings from their joint meetings, and poetry in lěshōn ha-qodesh, the holy tongue. ${ }^{10}$

7 On medieval Karaite exegesis, especially during its 'Golden Age' in the Middle East, including such authors as Daniel al-Qūmisī (9th c., Persia/Palestine), Salmon ben Jeroḥam (Ioth c., Iraq/Palestine), Jacob al-Qirqisānī ( Ioth c., Iraq), Yefet ben `Eli (Ioth c., Iraq/Jerusalem), and Joseph ben Noah (I I th c., Palestine), see, e.g., Goldstein 201 I, Zawanowska 2012, and Robinson 2012. For an overview of the history of Karaite exegesis, including also its later development in the Byzantine Empire, see Frank 2000. Recent publications on medieval Hebrew Karaite poetry include, e.g., Yeshaya's (2OI I, 20I4) two volumes of secular and liturgical Hebrew poetry by the twelfth-century Egyptian Karaite Moses Dar'ì.

8 The most recent works on Eastern European Karaite history and literature include, e.g., Akhiezer and Shapira 200 I, Akhiezer and Lasker 2006, Kizilov 2009, Shapira and Lasker 20 I I. After the collapse of the Soviet Union, the Firkovich archives, stored in the Russian National Library in Saint Petersburg, have opened up countless new avenues for the study of Karaite Judaism. For more on these archives, see, e.g., Sklare 2003: 905-9.

9 Today there are approximately 30,000 Karaites in the world. Most of them are Egyptian-born Karaites living in Israel or USA. Karaites (also known as Karaims) of Eastern Europe and the former Soviet republics number a few hundred only.

10 For Eastern European Karaite works in Hebrew and in Karaim (including research literature, journal articles, etc.), see Walfish and Kizilov 20 I I: $127 \mathrm{ff}$. For a brief overview on Karaite literary culture in Poland-Lithuania, see Tuori 201 3a: 52-6. 
For Polish-Lithuanian Karaite scholars, Hebrew poetry was an instrument for expressing devout feelings, and discussing intricate theological, philosophical, and mystical topics. With their use of quantitative-syllabic metres and their choice of strophic structures, the Polish-Lithuanian Karaite poets follow the Sephardic (Andalusian) tradition of poetry and poetics. ${ }^{11}$ A close reading of their poetry offers an opportunity to understand their culture and view of the world, their literary choices, achievements, and desires, and even their version of Judaism from a renewed perspective. ${ }^{12}$ In Eastern Europe Karaites also wrote 'ăqèdōt: penitential poems on the theme of the binding of Isaac. These poems will be our next focus.

\section{Recreating the liturgy of repentance: 'ăqēdōt in Hebrew poetry}

And it came to pass after these things, that God did prove Abraham, and said unto him: 'Abraham'; and he said: 'Here am I' (Gen. 22:I).

The binding of Isaac (Gen. 22:I-I 9) is one of the most well-known biblical narratives, and certainly one of the most emotionally loaded ones. In this passage, God commands Abraham to take his son Isaac to the land of Moriah, where he must sacrifice the beloved child as the ultimate trial of faith. At the end of the journey, Abraham binds his son and prepares for the deed when a divine voice of an angel halts him from the final act of killing. A ram is sacrificed instead of the son. Abraham has now established his unwavering loyalty to God. The angel delivers the divine blessing to Abraham: God will multiply his seed as the stars of the heaven and the sand on the seashore.

Told in nineteen verses in the Book of Genesis, this perplexingly concise tale leaves a lot to imagination. It is hardly surprising that countless Jewish commentators have tackled with the complexities of a father sacrificing his child. ${ }^{13}$ In the Mishnaic tractate Avot $(5: 3)$, the binding is mentioned as one of the ten trials of Abraham, ${ }^{14}$ and in rabbinic literature the motives and emotions of the

11 A short review of the multifaceted history of Karaite Hebrew poetry and its research, see Tuori 20Ir: 372-9 and 201 3b; and Weinberger r 998: 408-3 I.

12 For poetry as a valid source for understanding Jewish history, see Tanenbaum 2002: $4^{-6 .}$

13 On the myth of 'áqeedā in Jewish traditions, see, e.g., Spiegel I 993, Sagi I 998, and van Bekkum 2002. The harrowing narrative has inspired countless artists, poets, and authors, especially after the Holocaust.

14 While in Avot the trials are not listed, later commentators, including Maimonides in his Commentary on the Mishnah, mention the binding as the final, tenth trial of 
protagonists are carefully studied and re-interpreted. In the early Palestinian targumim (Aramaic translations of the Hebrew Bible), for example, Abraham reveals to Isaac that he will be sacrificed, Isaac himself requests to be bound, and Abraham entreats that God will remember his sacrifice and Isaac's willingness

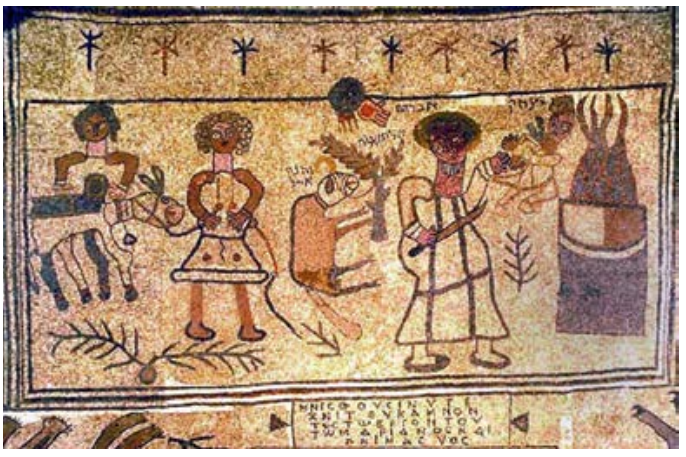

Sacrifice of Isaac, Beit Alpha Synagogue.

Photo by Talmoryair, 2007. Wikimedia Commons. (Davies and Chilton I978: 540). In the Babylonian Talmud (Sanhedrin 89b) rabbis reveal that it is actually Satan himself who challenges God to test Abraham, thus echoing the misfortunes of Job (van Bekkum 2002: 87). Isaac, the helpless victim of the Book of Genesis, in particular, gains agency. In an early Palestinian midrash, ${ }^{15}$ Isaac is a 37-year-old man, thus possessing enough strength and maturity to put up some resistance to his father. However, rather than remaining a passive victim he willingly prepares himself for slaughter (Elitzur I 999).

In the Mishnaic tractate Ta'anit (2:4), ${ }^{16}$ the binding of Isaac is referred to in connection with the so-called remembrance prayers (zikhronot) for the New Year, Rosh ha-Shana. In a similar vein, in the Babylonian Talmud (Rosh ba-Shana I6a) the sounding of the Shofar (ram's horn) on Rosh ha-Shana is associated with the ram sacrificed instead of Isaac (Fleischer I975:470). According to P. R. Davies and P. D. Chilton (I978: 534), "[ $t$ ] he links between the Aqedah and the New Year liturgy are the theme of remembrance and the ram's horn': God will remember his promises to Abraham, and the ram will be sacrificed instead of the son. Thus, the narrative was used in similar contexts by the first post-biblical Hebrew poets responsible for the creation of liturgical poetry (Heb. piyyütìm) for the embellishment of nascent Jewish prayer service

Abraham. For a concise paraphrase of the narrative, extracted from the available midrashic and aggadic sources, see Ginzburg 2003: 225-33.

15 Genesis rabba 56:8; see also Ginzburg (2003: 228-9), where Isaac exclaims: 'Blessed is the Lord who has this day chosen me to be a burnt offering before Him.'

16 'For the first [ending] he says, "He who answered Abraham on Mount Moriah will answer you and hear the sound of your cry this day. Blessed are you, O Lord, redeemer of Israel."' (Translated by Neusner I 988: 309) 
(Münz-Manor 2010: 354), ${ }^{17}$ and eventually the liturgical environment of the

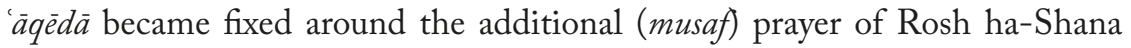
(Davies and Chilton i 978: 534).

In the ensuing medieval Hebrew poetic tradition, 'ăqēdōt were included under the sub-category of sélīhōt, penitential poems, which are recited on specific fast days and, most poignantly, during the penitential period between the New Year and the Day of Atonement (Schirmann 1997: 696). One of the most famous 'ăqēdōt, 'Ét sha 'ărē rāṣōn lě-hippàttēah ('When the gates of favour will open') is attributed to the North African poet Yehuda ben Shemu'el ibn Abbas (Fez, later of Baghdad, I 2th c.) (Davidson I 970, III: 296, no. I053; Schirmann I 997: 280-I; Zunz I 865: 2 I6). The poem is part of the Sephardic liturgy of the New Year and recited immediately before the sounding of the Shofar. ${ }^{18}$ The poem rapidly spread all over the Jewish world, and even the eminent Moses Maimonides (Egypt, I I38-I 204) wrote a poem following ibn Abbas's style (Schirmann I997: 28 In8). ${ }^{19}$

Nevertheless, the crystallization of the 'ăqèdot as a specific poetic genre in the wider context of sélinhōt occurred relatively late. Because the themes from the biblical story are frequently used in liturgical poetry, many poems merely referring to Gen. 22 were later understood as genuine 'ăqēdōt and eventually published in specific sections in Ashkenazi and Sephardic Siddurim (Fleischer I 975: 470). Ezra Fleischer ( $1975: 470$ ) suggests that the initiators of the genre were not Sephardic but Ashkenazi Jews in Western Europe. Me'ir ben Yiṣhaq of Worms (I Ith c.) and Ephraim of Bonn (II32-I200) were among the first Ashkenazi poets to write penitential poetry (sèlīhōt) focusing on the binding of Isaac. ${ }^{20}$ The themes of sacrifice and martyrdom were particularly pertinent for the Ashkenazi communities of the period, ravaged as they were by the Crusades.

17 The classical period of Hebrew liturgical poetry is dated to the 6th-8th century (Palestine and Babylonia), and includes anonymous poems, and poetry by known authors such as Qallir, Yannai, and Yose ben Yose.

18 In the popular Israeli site dedicated for medieval piyyūtitm, there are as many as twenty-five liturgical melodies for Yehuda ibn Abbas's poem, including recent recordings from Jewish communities in Kurdistan, Salonica, Italy, Iraq, Turkey, Tunisia, Yemen, and Israel.

19 Ann̄ mazkìr hay-yōm (Davidson I 970, I: 306, no. 6742; Zunz I 865: 462); for a later Italian imitation of 'Ét sha ărē rāṣōn, see Schirmann i 997: 44In6r. According to Hayyim Schirmann (1 997: $28 \mathrm{In} 8$ ), imitations of ibn Abbas's poem mainly by Sephardic and Mizrahi Jews soon acquired the Hebrew adjective 'abbasi ('in the style of ibn Abbas').

20 For an English translation of the 'äqēdā Et ăvotay ănì mazkìr by Ephraim of Bonn, see Carmi I98 r: 379-84. 
Chillingly, Gen. 22 provided legitimization for the killing of one's children as part of the sanctification of the divine name (qiddūsh ha-shèm) rather than subjecting them to the violence of the Gentiles and forced conversion. Indeed, the implications of this tragic narrative have been rather dire in the course of Jewish history (Sagi I 998: 52).

\section{Notes on 'ăqēdōt in early modern Karaite tradition}

The burnt offering, the one offering the sacrifice, and Mount Moriah (the refrain in the 'àqeedà of Yehuda ben Zerubbabel).

The Karaite 'ăqèdōt are published as the last section of the third volume of the Karaite Siddur (pp. 3 I 8-3o), which contains the Karaite prayers for the Day of Atonement. The poems are printed after other penitential poems, seelizhöt (pp. 294-3 I 8). This particular section in the Lithuanian Siddur only contains poems by Karaite authors. ${ }^{21}$ The most famous Rabbanite 'àqeedā, Yehuda ibn Abbas's 'Ét sha 'ărē rāṣōn, is published twice in the Lithuanian Siddur: in the first volume of the Karaite Siddur (pp. 408-9) among the liturgical poems for the Sabbath when the weekly Torah portion of Vay-yerra $\left(\right.$ Gen. I 8:I-22:24) is read, ${ }^{22}$ and in the fourth volume (pp. $25^{2-3}$ ) among the prayers for pilgrims heading towards Jerusalem. That rabbinic poetry is published in Karaite Siddurim is not surprising: while Karaites of any given time have been prolific Hebrew poets, rabbinic liturgical poems had already become an integral part of Karaite liturgy early in its history (Weinberger I 998: 409). ${ }^{23}$

21 In addition, 'ăqèdōt in the third volume of the Siddur include two Karaite poems that are not of Polish-Lithuanian origin: an 'āqēeda by 'Ezra ben Eliyyahu Firūz (1 5 th-16th

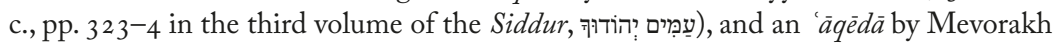

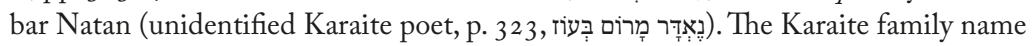
Firūz was originally Persian, and members of the family were scattered all around the Middle East (Walfish and Kizilov 20 I : 66).

22 Karaite and Rabbanite Torah readings have followed the same yearly cycle, beginning in the month of Tishri, ever since the fifteenth-century rapprochement of the Byzantine Karaism with rabbinic Judaism (Attias I 992: 290).

23 The early formation of the Karaite liturgy and its relationship to poetry remains obscure: early Karaites preferred biblical texts (especially Psalms and Lamentations) as the only legitimate source for liturgy. According to Yeshaya (20 I 4: I 4), the twelfthcentury Egyptian Karaite poet Moshe Dar'i represents one of the earliest known Karaite sources writing liturgical poetry. 
All of the poets are Polish-Lithuanian Karaites, who lived between the seventeenth and eighteenth centuries. ${ }^{24}$ A complete list of the Polish-Lithuanian Karaite 'ăqèdōt and English translations of their titles follow:

I. Yehuda ben Zerubbabel (Troki, I 7 th c.):

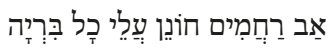

('Merciful father who pardons all creatures')

2. Zerah ben Natan (Troki, I $_{578-1657 / 8):}$

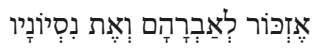

('I will remember Abraham and his trials'),

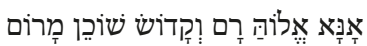

3. Yoshiyahu ben Yehuda (Troki, d. c. r 660):

('Please, high and holy God, dwelling in heights')

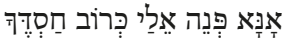
('Please, turn towards me in the multitudes of Your mercy'),

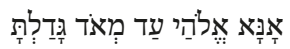
('Please, my Lord, how great You are') 4. Abraham ben Aharon (Nowomiesto, Lithuania, I7th c.):

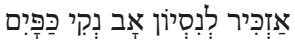
('I will keep in remembrance the trial of the innocent father') 5. Shelomo ben Aharon (Troki, I670-I 745):

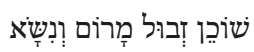

('The one dwelling in the heaven is elevated and high'),

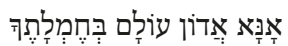

('Please, Master of the Universe, in your grace')

6. Yosef ben Yișhaqu (Troki, I 7 th c.):

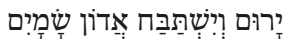
('May the Master of the heavens be high and praised'),

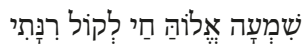

('Hear, o living God, the sound of my joy')

7. Moshe ben Shemu'el (of Szaty, or of Troki, I7th c. or I 8th c.?): ${ }^{25}$

24 On biographical details of these Polish-Lithuanian Karaites (excluding Moshe ben Shemu'el), see Tuori 2or 3 a: 6o-82.

25 The identity of Moshe ben Shemu'el is unclear. The Polish Karaite Mordokay ben Nisan (d. c. I709) wrote a lamentation on the death of one Moshe ben Shemu'el of Troki (Mann I 93 I: I 257-62). Moshe ben Shemu'el of the Lithuanian town of Szaty (Šèta) asks Yosef ben Yiṣhaq (see above) to decorate a liturgical text in green, black, and red (Mann I93I: 735, I23I-3). 
The Lithuanian Karaite Siddur is the only place where these eleven PolishLithuanian Karaite 'ăqèdōt have ever been published. The editor of the Vilna Siddur, the Troki-based Pinehas Malecki (I854-1928), used local, old manuscripts while preparing the prayer book for publication. ${ }^{26}$ For example, the heading of the 'áqeid $\bar{a}$ by Moshe b. Shemu'el (p. 329) indicates that the manuscript Malecki used belonged to the poet himself. Identification of the poets is based on the headings added to the poem by Malecki, and the acrostics of the poems, which reveal the name of the author and his patronym, or, alternatively, names of friends or relatives. Some of the headings also contain the date and year of the poem's composition. ${ }^{27}$

Leopold Zunz (I865: 216) notes that Karaites had adopted Yehuda ibn Abbas's poem 'Ét sha ărē rāṣōn as part of their liturgical repertoire. ${ }^{28}$ Furthermore, there is an intrinsic connection between ibn Abbas's poem and Karaite 'ăqèdōt: all the Polish-Lithuanian 'ăqèdōt are written to resemble the metric structure of this twelfth-century Rabbanite poem, as demonstrated by the following example:

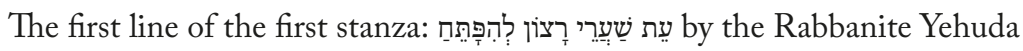
ibn Abbas:

'èt sha ‘üre rāṣōn lě-hippāttēāh ${ }^{29}$

26 See the title page of the Vilna Siddur (vol. IV). Some of the manuscripts Malecki most likely used as a source are still extant; see, e.g., manuscript A 259, עקדות וזמירות מנהג קראים (in 28 fols.) at the Institute of Oriental Studies of the Russian Academy in Saint Petersburg. Because I have not had access to any of these manuscripts, comparison between different versions of these poems is not yet possible.

27 For example, Yehuda ben Zerubbabel wrote his poem in I640/4I, and Abraham ben Aharon in $1686 / 87$. Nevertheless, one must always be cautious when studying texts printed in later, modern sources. It is a well-known fact that editors often changed the contents of Hebrew texts in nineteenth-century Karaite Siddurim for various ideological and religious reasons, including political sensitivity (Goldberg I957: I08; Miller I 993: 17 ).

28 Alongside the Lithuanian Siddur (1890-2) it is also published in the Crimean Karaite Siddur (Siddūr hat-těfllōot kĕ-minhag haq-qärä̀ìm I 836: I45).

29 Short syllables are in boldface.

30 Read from left to right; - represents a long syllable, ^ a short one (i.e., a syllable with a sherwa mobile or one of the hătăfim); in the transliteration the short syllable is in 


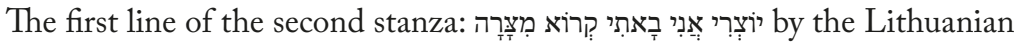
Karaite Yehuda ben Zerubbabel:

$$
\begin{aligned}
& \text { yoṣ-ri } \hat{a}-n \bar{\imath} \underline{b} \bar{a}-t \bar{i} q \breve{e}-r \bar{o} \text { miṣs } \\
& -\wedge^{\wedge}-1--\wedge-1--- \\
& \text { feet: }{ }^{31} \text { mitpa ‘ălìm / mitpa ‘̆ ălìm / nif' ālìm }
\end{aligned}
$$

This originally Andalusian Hebrew poetic metre is known in research literature by the Hebrew name $h a-s h a \bar{l} e m$ II, originally adapted from the classical Arabic metre kāmil by tenth-century Spanish Jewish poets (Yellin I972: 48). Furthermore, much like the poem 'Ét sha 'ărē rāṣōn by ibn Abbas, Karaite 'ăqèdōt are strophic; that is, they are made out of a certain number (between 4-5) of lines grouped into stanzas, which always share a common rhyme, ending with a refrain: AAAAA $\mathrm{A}, \mathrm{BBBBA} \mathrm{A}$, etc. ${ }^{32}$ In the refrain of the 'a $q \bar{e} d \bar{a}$ 'Merciful father', Yehuda ben Zerubbabel writes:

$$
\text { עוֹלָה וְהַמַעְלֶה וְהַר מוֹרְיָּה }
$$

The burnt offering [Isaac], the one doing the sacrifice [Abraham], and Mount Moriah

The refrain bears a striking similarity to the refrain in ibn Abbas's poem: 'The

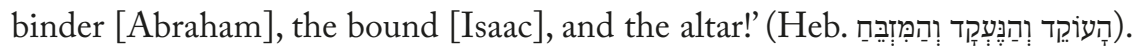
Both refrains refer to the two main protagonists with epithets (Abraham as an active subject, Isaac as a passive object) as well as the place of action (Mount Moriah and the altar, which in later Jewish interpretations is equated with the place of the future Temple).

It is probable that the Polish-Lithuanian Karaite poets, knowing ibn Abbas's poem as part of their liturgical tradition, used this rabbinic poem as a source of inspiration and probably even sang all the ăqèdōt to an identical melody. Such imitation (or, to use a more neutral term, modelling) of prestigious poems is very typical in pre-modern Hebrew poetry. ${ }^{33}$ New poems are formed by

boldface. For the basic units of the Andalusian Hebrew quantitative metre, see, e.g., Fleischer I975: 34I-3.

31 On feet in medieval Hebrew poetry, see, e.g., Pagis I 976: I I3, I I6- I 7; Weinberger I998: xxii-xxiii.

32 This strophic structure is known in research as pseudo-muwashshah (Fleischer I 975: 349-52).

33 On medieval Jewish poets (Moshe ibn Ezra, Yehuda ha-Levi, Abraham ibn Ezra etc.) who composed imitations of Arabic strophic poetry, see Stern 1974: 78-9. On 
following the poetic form (e.g., prosody, rhyme schemes) of, and even taking wordings from, the model poem. This productive poetic technique always respects the source of inspiration, and the 'original' names were often added to the headings of new creations as instructive details.

Drawing much from the Bible, the language of the 'ăqèdot is not 'pure' biblical Hebrew, ${ }^{34}$ but,

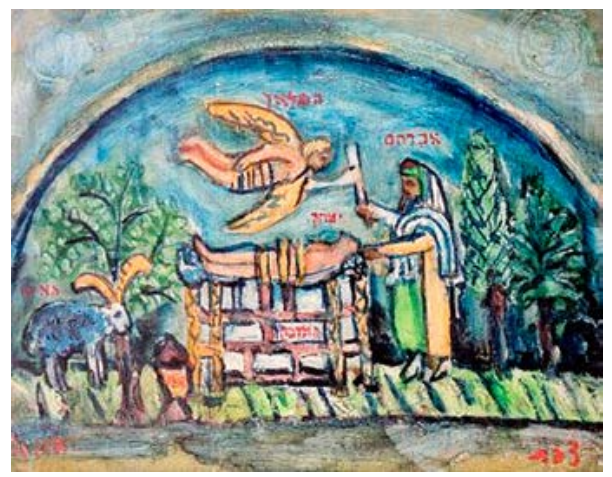

Sacrifice of Isaac. Photo by Israeliarthistorian, 2014. Wikimedia Commons. rather, represents a mix of biblical citations, allusions, paraphrases, and merged rabbinic and medieval linguistic structures. ${ }^{35}$ While Karaite Judaism draws its primary religious authority from the written Torah and its interpretation, this has never stopped Karaites from employing post-biblical Hebrew. ${ }^{36}$ The quantitative-syllabic metric system affects the linguistic choices: the metre rigidly demands the syllables to appear in a prescribed order and quality, often at the expense of minor grammatical errors, such as mixed gender forms. The biblical narrative of the binding is a strong component in the language of the poems, and the verbs and nouns taken from Gen. 22:I-I9 are particularly pervasive. One example suffices:

imitation as a technique by early modern Eastern European Karaite poets, see Tuori 20I 3 a: i $5 \mathrm{ff}$.

34 This remark is pertinent because of long-lasting statements of Karaites using only biblical idiom; see, e.g., Allony r 969: 32. Then again, even the noun 'äqédā of the root ' $q d$ (with the biblical verb 'to bind') is non-biblical. For the first time the noun appears in the Mishna, referring to the tying of the sacrificial lamb (Davies and Chilton I978: 5 I4-I5).

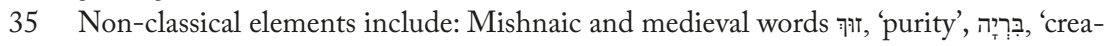

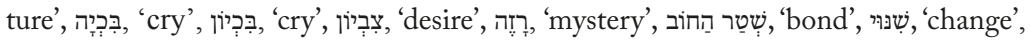
י., 'unity'; and the use of the preposition - לִ as a marker of object, the use of Mishnaic

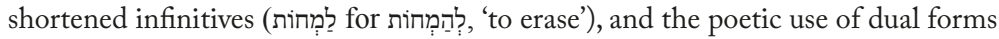
as rhyme-endings. Once even the use of Aramaic is attested: Yosef ben Yișhaq in his 'àqeed ('May the Master of the heavens be high and praised', p. 327) employs an Aramaic phrase רַמְשָׁא צִפְרָ ('night and day'), a phrase that occurs in Targum Onqelos (Ex. I 8:I 3). On the use of non-biblical Aramaic in Polish-Lithuanian Karaite poetry, see Tuori 2013a: 218-20.

36 On Karaite Hebrew in general, see Maman 2003, Tirosh-Becker 201 2; on PolishLithuanian poetic idiom and its post-classical elements, see Tuori 20 г 3a: 177-9. 
עֵת הֶֶׁלָהוּ אָב לְעוֹלוֹתָים

When father offered him (Isaac) as a burnt offering 37

In this example the verb 'raise, offer' (הֶֶֶלָ) is an allusion to the biblical narrative, when Abraham is ordered to offer his son as a burnt offering (Gen. 22:2), and finally when a ram is offered instead of the son (Gen.22:13).

\section{The function of the 'ăqēdōt in Karaite liturgy}

The function of the 'ăqèdōt - the actual performative context where the poems were recited - is coded into the second stanza of the 'áqe $\bar{e} \bar{a}$ 'Merciful father who pardons all creatures' by Yehuda ben Zerubbabel:

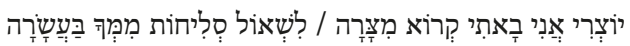

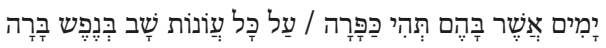

My Creator, I have come to call from (my) trouble, / to ask Your forgiveness on these ten / days during which atonement will befall / on all the sins returning with a pure soul.

Karaites - like Rabbanite Jews - recited 'ăqēdōt in the month of Tishri during the ten days between the Day of Trumpeting and the Day of Atonement (Yom Kippur). In Karaite tradition, the first day of Tishri is known by its biblical name, 'the Day of the Trumpeting' (Heb. yōm těru' 'à), as opposed to the established rabbinic term, Rosh ha-Shana (New Year). ${ }^{38}$ Parallel to the rabbinic days of awe (yāmìm norā'im), the Karaites knew the period as the ten days

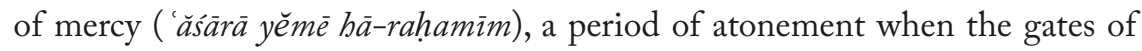
mercy are opened for those who repent (Weinberger i 991: 430-ingo). The Day of the Trumpeting launches the period of repentance, when the patriarchs Abraham and Isaac are remembered as the paragons of steadfastness. The image of gates opening is referred to in the 'áqéd 'Please, turn towards me in the multitudes of your mercy' by Yoshiyahu ben Yehuda:

37 The noun 'burnt offering' is in the dual form for poetic reasons: all the fifth lines in this poem are rhymed with the syllable -tãyim, grammatically the feminine dual form.

38 On the changes in the concept of the Day of Trumpeting (from a day of joy into a day of repentance) in medieval Karaite tradition, see Miller 1999. Initially Karaites opposed the use of the term 'new year' for the Day of the Trumpeting, since Tishri is the seventh, not the first month of the year (Miller I999: 538). 


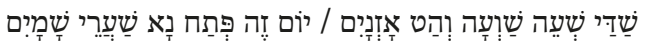

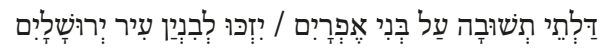

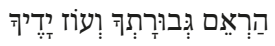

\begin{abstract}
Almighty, perceive my cry and incline your ears: / (On) this day, please, open the gates of the heavens, / the doors of repentance for the Children of Ephraim, ${ }^{39} /$ may they be entitled to (see) the rebuilding of the city of Jerusalem. Display them Your might and the strength of Your hands!
\end{abstract}

Thus, 'ăqèdōt represent a cry of repentance: poems typically begin with expressions of a deep sense of guilt, and end in a plea to remove this guilt. God will have mercy on the wretched congregants on account of the good deeds of previous generations. In the Babylonian Talmud (Rosh ha-Shana I 6a), the binding of Isaac and God's remembrance are connected: on account of the steadfast faith of Abraham, his descendants, the Jewish people, may also be kindly remembered. Indeed, two of the Karaite 'ăqè $\bar{c} t$ begin by evoking the memories of the past: 'I will remember Abraham and his trials' by Zerah ben Natan, and 'I will keep in remembrance the trial of the innocent father' by Abraham ben Aharon. In the Zerah's poem, the refrain goes as follows:

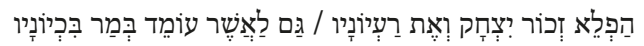

Marvellous one, remember Isaac and his strivings, / as well as the one who stood with his bitter cry [Abraham].

That the good deeds of the forefathers redeem the children is mentioned already in the Mishnaic tractate Avot 2:2. ${ }^{40}$ The loyalty and good deeds of Abraham and the divine promise are a blessing for the future generations:

39 The epithet 'the children of Ephraim' (referring to the people of Israel, from Ps. 78:9, and here especially to Karaites) appears in the ăqèdōt three times.

40 'For the merit of their fathers strengthens them, and their righteousness stands forever' (translated by Neusner 1988: 675). Although Karaites did not esteem the Mishna on the same level as the written Torah, they did study rabbinic works as much as was possible. Mishnaic tractates such as the Avot were easily approachable; the Babylonian Talmud, written in Aramaic, less so. As noted by Golda Akhiezer and David Lasker (2006: I 5n29), Polish-Lithuanian scholars often quote from certain central rabbinic texts, especially Avot. 
according to the rabbis, ${ }^{41}$ the Torah was given solely on account of the good deeds of Abraham. Accordingly, Abraham ben Aharon writes in his poem:

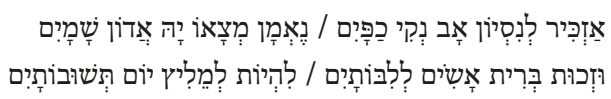

I will keep in remembrance the trial of the innocent / and loyal father, whom the Lord, the Master of the heavens had found, / and on account of this covenant I will keep in (my) heart / (for Abraham) to be the intercessor (cf. Job 33:23) (on) the day of repentance. ${ }^{42}$

The poem by Abraham ben Aharon focuses on the merits of the fathers, whose example will help erase the abominable sins of the inherently inferior current generation.

Anyone who has visited a Karaite synagogue - known in the Karaim language as a kenesa - knows that the Karaite liturgy differs from the rabbinic service mainly because it draws the bulk of its material directly from the Bible. Another, more visible difference is that Karaite service requires physical participation. ${ }^{43}$ The physical postures of Karaite prayer include standing, bending, inclination, kneeling, prostration, and spreading the hands, each derived from biblical examples ( $\mathrm{I}$ K 8:22, ${ }_{2} \mathrm{C}_{20} 0: 5,{ }_{2} \mathrm{C}_{29}$ :29, and Ps. I 34:2) (Frank 2003: 572; Goldberg I 957: 8-29). ${ }^{44}$ In the 'àqē $\bar{e}$ 'I will remember Abraham and his trials', Zerah ben Natan describes physical aspects of prayer:

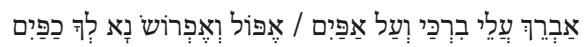

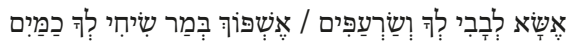

I will kneel down, prostrate / face down and spread my arms for You, I will raise my heart to You, and my worries / I will pour to You with the bitterness of my complaint like water.

41 Exodus rabba 28:1: לא נתנה לך תורה אלא בזכות אברהם, 'The Torah was given to you only on account of the good deeds of Abraham' (my translation).

42 'Heart' and 'repentance' appear here in dual form due to rhyme (-tāyìm, -tāyìm).

43 In rabbinic service, prostration occurs during the liturgy of Rosh ha-Shana and Yom Kippur.

44 Muslim influence was key in the development of early Karaite theology, philosophy, and literature; there have been speculations on the affinities between Karaite and Muslim prayer, especially in connection with physical postures (Frank 2003: 572). 
In 'I will keep in remembrance', Abraham ben Aharon describes the postures of the repentant congregant:

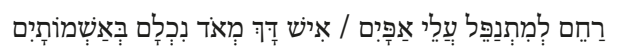

Have mercy on the one who prostates, / the exceedingly oppressed and ashamed man in his guilt.

These subtle allusions to Karaite liturgy in the Polish-Lithuanian Karaite ăqèdot are not just figures of speech: they also reflect the reality of the PolishLithuanian Karaite synagogue service during the ten days of mercy.

\section{Characters: Sarah, Abraham, Isaac, angels, and the Land of Moriah}

The main protagonists in the Karaite ăqeedòt are Abraham, Sarah, Isaac, and the representative of the divine voice (an angel of God, or a band of angels). In addition, minor roles are played by the sacrificial ram and the two servants Abraham takes with him to the Land of Moriah.

The status of Sarah, in particular, is worthy of further investigation, because she is absent from the original biblical narrative. In 'Merciful Father who pardons all creatures' by Yehuda ben Zerubbabel, Sarah opens her mouth:

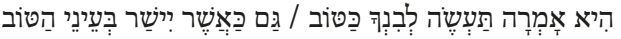

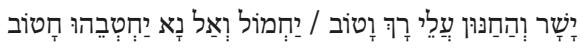

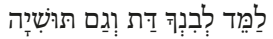

She [Sarah] said: 'Do to your son as is good, / as well as what is fair in the eyes of the Good [i.e. God]. / He who is upright and merciful to the young and tender (Gen. I8:7) / will have mercy - may He please not cut him [Isaac] down. Teach the Law to your son, as well as wisdom.'

Here Sarah is answering Abraham, who in the previous stanza has offered her a blatant but merciful lie: that he is taking their young son away to teach him how to properly serve God: 'He will learn it [divine wisdom], and will pray in front of Him [God].' It was only in the previous chapter in the Book of Genesis (Gen. 2I) that Isaac was born to the ninety-year-old Sarah, and now God is claiming this miracle child. 
Using Sarah as a character is not an original idea on the part of the Karaite poet. In the 'àqeeda of Yehuda ibn Abbas, Abraham uses an identical excuse. ${ }^{45}$ Abraham's need to explain to his wife the absence of their son is taken from the early aggadic Midrash Tanhuma on Gen. 22 (Elitzur I999). ${ }^{46}$ In Yehuda ben Zerubbabel's poem Sarah has a bitter inkling of the future:

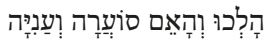

They (Abraham and Isaac) left, and the mother was afflicted and tossed with tempest (Is. 54:I I).

In the same poem Abraham sheds tears on account of his bloody mission immediately after Isaac asks the famous question (Gen. 22:7): 'Where is the lamb for the burnt offering?"

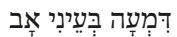

A tear in the eye of the father...

Once again, that Abraham weeps is a motif present also in ibn Abbas's poem. ${ }^{47}$

In the biblical narrative (Gen. 22:I I and 22:I5), only one voice of an angel ('the angel of the Lord') is heard: the voice orders Abraham to halt in the midst of the killing. In the midrashim, angels turn up in plural, and even the archangel Michael is summoned to help (Ginzburg 2003: 229). In Yehuda ibn Abbas's poem, as well as in some of the Karaite 'ăqèdōt, one angel is not enough; multitudes of them enter the scene. In 'Merciful Father' by Yehuda ben Zerubbabel, angels take the forms of the mystical creatures (ar'él and hashmālìm) ${ }^{48}$ described in the visions of Ezekiel and Isaiah:

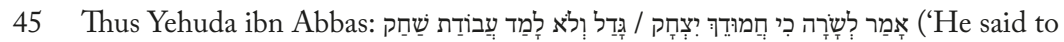
Sarah: 'For your sweet one, Isaac, / has grown and has not yet learnt the service of the heaven', (my translation) (Karaite Siddur, vol. I: 409).

46 Tanbuma, Vay-yērä' 22. For an English paraphrase of Abraham's excuse, see Ginzburg 2003: $225-226$.

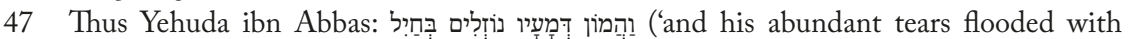
force...') (Karaite Siddur, vol. I: 409). On Abraham's tears in early rabbinic lore, see Ginzburg 2003: 229.

48 Both biblical nouns are used as epithets for angels in early liturgical Hebrew poetry (David 2001: 39, I I2). 


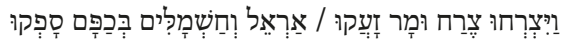

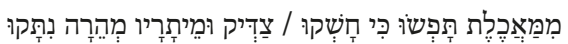

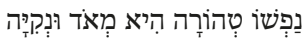

They shouted loudly and bitterly cried, / the valiant one (Is. 33:7) and electrums (Ez. 8:2) clasped with their hand(s) (Num. 24:10): / they grasped the knife because they loved / the righteous one, and swiftly his ropes [binding Isaac] were cut.

His (Abraham's) soul is very pure and untainted.

The angels do not merely cry loudly but also physically grasp the knife Abraham has raised. The angels with teary eyes are familiar from Genesis rabba $(56: 5)$ :

Now at the moment at which our father, Abraham, stretched out his hand to take up the knife to slaughter his son, the ministering angels wept. That is in line with this verse: 'Behold their valiant ones cry outside' (Is. 33:7). ${ }^{49}$

It is noteworthy that both in Genesis rabba and in the Karaite poem, the angel giving the divine order to Abraham is known as 'the valiant one', ar'el. ${ }^{50}$

In Gen. 22:2 we are informed that the destination, the Land of Moriah, where Abraham must sacrifice his son, will eventually be shown to him by God. This was too vague for the early rabbis, who added that Abraham and Isaac recognize their destination by 'a column of fire from the earth until heaven'. 51 The name Moriah appears in the Bible only twice. ${ }^{52}$ Whether these names refer to the same place is uncertain. Because the Land of Moriah in later Jewish thought was understood to be identical with Mount Moriah, the place where Solomon builds the Temple (2 Chr. 3:I) in Jerusalem, the idea of a divine light emanating from there makes perfect sense. In Genesis rabba (55:7), for example, one of the rabbis explains Moriah as 'the place from which light (אil) enters the world' (Neusner I 985: 272). In Yehuda ibn Abbas's poem, Moriah is the

49 Translated by Neusner ( $1985: 282)$.

50 In Yehuda ibn Abbas's poem, the angels are of ānīm and galgālìm, originally biblical nouns for wheels and whirls of Ezekiel's visions (cf. Ez. I:16, го:2), but used in early liturgical Hebrew poetry as epithets for angels (David 200r: 26, 68).

51 From Pirqe di-rabbi Eliezer; quoted in García Martínez 2002: 52.

52 As the Land of Moriah in Gen. 22:2, and as Mount Moriah in 2 Chr. 3:1. 
mountain where 'the glory shines forth' (2nd stanza). Likewise, according to Yehuda ben Zerubbabel, Abraham and Isaac recognize Moriah because it emits a luminous light, compared to the light of the moon: ${ }^{53}$

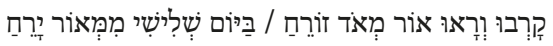

They approached (the mount) and saw a brightly shining light / on the third day, (like) from the light of the moon.

Yehuda ben Zerubbabel further elaborates the destination with 'fragrant spices, myrrh, nard, and henna'; an exegetical interpretation of Moriah as the place of incense offering in the Temple, derived from the noun mor, 'myrrh'. 54

From the discussion above we may conclude that the Karaites are rewriting the biblical narrative of the binding after models supplied by the Rabbanite poet Yehuda ibn Abbas in his popular 'àqeeda and by early Jewish legends discussed in medieval rabbinic and Karaite exegetical works: ${ }^{55}$ the silent wife and mother, Sarah, has a voice, weeping angels with mystical forms function as divine messengers, and the mythical destination Moriah is the shining dwelling-place of God.

\section{Conclusions: Karaite poetry and prayer in early modern Poland-Lithuania}

In this article I have introduced the readers to Polish-Lithuanian Karaite poems recited during the penitential period between the Day of the Trumpeting and the Day of Atonement. The poets retell the story of the binding of Isaac with selected themes from rabbinic and medieval Jewish traditions, thus offering new perspectives and motives for the characters of the originally biblical narrative.

53 Incidentally, in ibn Abbas's poem the Moon symbolizes Isaac, one of the lights shining

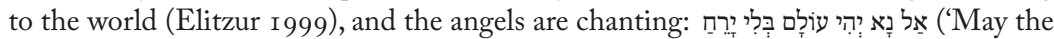
world not exist without the Moon [Isaac]', my translation).

54 See Rashi's commentary on Gen. 22:2:

אונקלוס תרגמו על שם עבודת הקטורת שיש בה מור נרד ושאר בשמים :And Onqelos translated it (Moriah) with the name of incense service, because it contain myrrh, nard, and other spices.'

55 Despite various examples above from rabbinic literature, we should not downplay the indigenous exegetical interpretations of the topic in medieval Karaite interpretations of Gen. 22.; for example, for Yefet ben 'Eli's (Ioth c., Iraq/Jerusalem) commentary on the Book of Genesis, see Zawanowska 2012. 
In addition, I suggest that Eastern European Karaites did not create Hebrew poetry out of thin air: their works have a legitimate place in the larger context of Hebrew and Jewish religious poetry. In terms of form and content, these seventeenth- and eighteenth-century 'ăqēdōt are dexterous imitations of the popular Sephardic poem 'Ét sha'ărē rāṣōn, written by the twelfth-century Rabbanite poet Yehuda ibn Abbas. To name one formal connection, each of the eleven Karaite 'ăqèdōt adhere to the same poetic metre and strophic form as ibn Abbas's poem. Karaite 'ăqèdōt may therefore be added to the long list of medieval and early modern poems written in the style of ibn Abbas. ${ }^{56} \mathrm{Ibn}$ Abbas draws from midrashic sources with fresh interpretations of Gen. 22, and the Karaite poets happily follow suit, without ever losing their own voices.

This introductory article does not aim to be an exhaustive review of the genre of 'ăqèdōt in Polish-Lithuanian Karaite use. First, these intriguing poems require a thorough philological analysis, aided by Eastern European manuscripts. Second, Karaite religious poetry requires familiarity not only with rabbinic literature, but also with original Karaite works, especially exegetics. In future these poems must be analysed again in the light of medieval JudeoArabic and Byzantine Karaite exegetical classics. ${ }^{57}$

PhD Riikka Tuori is a University Lecturer of Middle Eastern Studies at the University of Helsinki. She finished her thesis on Karaite Hebrew paraliturgical poetry at the University of Helsinki in 2013. In 2006-7, she was a Visiting Research Fellow at the Hebrew University of Jerusalem. In 2014, she worked as a Research Associate at Seminar für Judaistik, Goethe-Universität Frankfurt am Main. Her current research interests include early modern Judaism and Hebrew literature, Jewish mysticism and poetry.

\section{References}

Printed sources

Siddūr ha-těfillōt kĕ-minhag ha-qārāìm, vols. I-IV (Vilna, Ya aqob Shishman, I 89o-2

Literature

Akhiezer, Golda, and Daniel J. Lasker, 2006. “Sēfer ēlōn mōre”: qāṭēkīsīs lě-ḥinnūk qārā'ì mě-ha-mē’ā ha-shěmonē 'eśrě', Dōr lě-dōr, 27, pp. 7-38

56 Cf. Schirmann I997: 28 In6.

57 Sefer ha-mivhar, a commentary on the Torah by the Byzantine Karaite Aharon ben Yosef ( $1250-1320$ ), in particular, was a must-read also among Polish-Lithuanian Karaite scholars. 
Akhiezer, Golda, and Dan Shapira, 200 . 'Qara'im be-liṭa u-be-vohlin-galișya 'ad ha-me'a hy-yod-ḥet', Pe 'amim, 89, pp. I9-6o

Allony, Nehemya, I 969. Hāa'egrōn lěe-rab sě 'adyā gäòn (Jerusalem, The Academy of the Hebrew Language)

Attias, Jean-Christophe 1992. 'Intellectual leadership: Rabbanite-Karaite relations in Constantinople as seen through the works and activity of Mordekhai Comtino in the fifteenth century' in Ottoman and Turkish Jewry: Community and Leadership, ed. Aron Rodrigue (Bloomington, Indiana University Press), pp. $67-86$

Bekkum, Wout van, 2002. 'The aqedah and its interpretation in midrash and piyyut' in The Sacrifice of Isaac: The Aqedah (Genesis 22) and its Interpretations, eds Ed Noort and Eibert Tigchelaar (Leiden, Boston, and Köln, Brill), pp. 86-95

Carmi, T., I 98 I. The Penguin Book of Hebrew Verse (Harmondsworth, Penguin)

Cohen, Shaye D., 2006. From the Maccabees to the Mishnah (Louisville, Westminster John Knox Press)

David, Yona, 200 I. Leqsīqōn ha-kinnūyìm bi-lshōn ha-payyẹtānìm (Jerusalem, Rubin Mass)

Davidson, Israel, I 970. Thesaurus of Mediaeval Hebrew Poetry, vols. I-IV (New York, Ktav)

Davies, P. R., and B. D. Chilton, I978. 'The aqedah: a revised tradition history', Catholic Biblical Quarterly, 40(3), pp. 5 I 4-46

Elitzur, Shulamit I 999. Shìrā shel pārāshā: pārāshōt ha-tōrā běerě̀̃ ha-piyyūṭ (Jerusalem, Mossad ha-rav Kook), online publication <http://www.piyut.org.i1/articles/789. html> (accessed 31.5.2015)

'Ét sha 'ărè rāṣōn lĕ-hippāttēah [Yehuda ibn Abbas's poem], <http://www.piyut.org.il/ textual/24.html> (accessed 31.5.2015)

Fleischer, Ezra, I 975. Shirat ha-qodesh ha- 'ivrit bìme ha-benayim (Jerusalem, Magnes Press)

Frank, Daniel, 2000. 'Karaite Exegesis' in Hebrew Bible / Old Testament: The History of Its Interpretation, vol. I: From the Beginnings to the Middle Ages, ed. Magne Sæbø (Göttingen, Vandenhoeck \& Ruprecht), pp. I 10-28

-2003. 'Karaite prayer and liturgy' in Karaite Judaism: A Guide to its History and Literary Sources, ed. Meira Polliack (Leiden, Brill), pp. 559-90

García Martínez, F., 2002. 'The sacrifice of Isaac in $4 \mathrm{Q}_{22} 5$ ' in The Sacrifice of Isaac: The Aqedah (Genesis 22) and its Interpretations, eds Ed Noort and Eibert Tigchelaar (Leiden, Boston, and Köln, Brill), pp. 44-57

Gil, Moshe 2003. 'The origins of the Karaites' in Karaite Judaism: A Guide to its History and Literary Studies, ed. Meira Polliack (Leiden, Brill), PP. 73-I I 8

Ginzburg, Louis (I 909) 2003. Legends of the Jews by Louis Ginzburg, trans. Henrietta Szold and Paul Radin (Philadelphia, Jewish Publication Society)

Goldberg, P. Selvin, 1957. Karaite Liturgy and its Relation to Synagogue Worship

(Manchester University Press) 
Goldstein, Miriam, 20 I r . Karaite Exegesis in Medieval Jerusalem (Tübingen, Mohr Siebeck)

Jankowski, Henryk, 2003. 'On the position of Karaim among the Turkic languages', Studia Orientalia, 95, pp. I3 I-50

Kizilov, Mikhail, 2009. The Karaites of Galicia: An Ethnoreligious Minority among the Ashkenazim, the Turks, and the Slavs, 1772-1945 (Leiden, Brill)

Lasker, Daniel J., 200 I. 'Ha-qārā'̀ kĕ-“'āḥēr” yĕhūdī', Pe 'amim, 89, pp. 97-ıo6

Maman, Aharon, 2003. 'Karaite Hebrew' in Karaite Judaism: A Guide to its History and Literary Studies, ed. Meira Polliack (Leiden, Brill), PP. 485-503

Mann, Jacob, I93 I. Texts and Studies in Jewish History and Literature, vol. II (Cincinnati, Hebrew Union College Press)

Miller, Philip E., I 993. 'Prayer book politics: an attempt to print the Karaite Siddur in I 866 that was cancelled', Studies in Bibliography and Booklore, I 8, pp. I 5-26

—_ 1999. 'Karaite perspectives on Yôm Těrû' $\hat{a}$ ' in Kì Baruch Hu: Ancient Near Eastern, Biblical, and Judaic Studies in Honor of Baruch A. Levine, eds Robert Chazan, William W. Hallo, and Lawrence H. Schiffman (Winona Lake, IN, Eisenbrauns), pp. 537-4I

Münz-Manor, Ophir, 2oro. 'Liturgical poetry in the late antique Near East', Journal of Ancient Judaism, I (3), pp. 336-6 I

Neusner, Jacob, I 985 . Genesis rabbab: The Judaic Commentary to the Book of Genesis. A new American translation, vol. II, Parashiyyot Thirty-four through Sixty-Seven on Genesis 8:15 to 28:9 (Atlanta, GA, Scholars Press)

— 1988. The Mishnah: A New Translation (New Haven and London, Yale University Press)

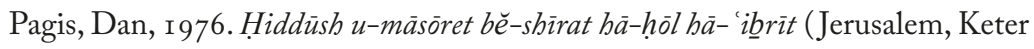
Publishing House)

Polliack, Meira, 2002. 'Medieval Karaism' in The Oxford Handbook of Jewish Studies, ed. Martin Goodman (Oxford University Press), pp. 295-326

—(ed.) 2003. Karaite Judaism: A Guide to its History and Literary Studies, Handbuch der Orientalistik, 73 (Leiden, Brill)

Robinson, James T., 20 1 2. Ascetisim, Eschatology, Opposition to Philosophy: The Arabic Translation and Commentary of Salmon ben Yeruham on Qohelet (Leiden and Boston, Brill)

Rustow, Marina, 20 i r. 'The Qaraites as a sect: the tyranny of a construct' in Sects and Sectarianism in Jerwish History, ed. Sacha Stern (Leiden and Boston, Brill), pp. I $49-86$

Sagi, Abraham, I 998. 'The meaning of the akedah in Israeli culture and Jewish tradition', Israel Studies, 3(I), pp. 45-6o

Schirmann, Hayyim, I 997. Tölědōt hash-shìrā ha- 'iḅrìt bi-sfārad han-nōṣrìt ū-bi-drōm șārfat (Jerusalem, Magnes Press)

Shapira, Dan, 2003. 'The Turkic languages and literatures of the East European Karaites' in Karaite Judaism: A Guide to its History and Literary Studies, 
ed. Meira Polliack (Leiden, Brill), pp. 657-707

Shapira, Dan D. Y., and Daniel J. Lasker (eds), 20 I I. Eastern European Karaites in the Last Generations (Jerusalem, Ben Zvi Institute for the Study of Jewish Communities in the East of Yad Izhak Ben-Zvi and the Hebrew University of Jerusalem)

Siddūr hat-těfillōt kĕ-minhag haq-qārā̀̀m, vols. III-IV(Gozlow, Mordokay Tirishkan, I 836 )

Sklare, David, 2003. 'A guide to collections of Karaite manuscripts' in Karaite Judaism: A Guide to its History and Literary Studies, ed. Meira Polliack (Leiden, Brill), pp. 893-924

Spiegel, Shalom, I 993. The Last Trial: On the Legends and Lore of the Command to Abraham to Offer Isaac as a Sacrifice. The Akedah, trans. with an introduction by Judah Goldin (Woodstock, VT, Jewish Lights Classic Reprint)

Stern, Samuel Miklos, r 974. Hispano-Arabic Strophic Poetry (Oxford, Clarendon Press)

Tanenbaum, Adena, 2002. The Contemplative Soul: Hebrew Poetry and Philosophical Theory in Medieval Spain (Leiden, Brill)

Tirosh-Becker, Ofra, 2o I 2. Ginzè hazal bě-sifrūt ha-qārā̄it bìmē ha-bēnayìm, vols. I-II (Jerusalem, Mossad Bialik)

Tuori, Riikka, 20 I r. "More didactic than lyrical”: modern views on Karaite Hebrew poetry', Studia Orientalia, I I I, pp. 37 I-92

-201 3a. Karaite zèmīrōt in Poland-Lithuania: A Study of Paraliturgical Poems from the Seventeenth and Eighteenth Centuries, $\mathrm{PhD}$ dissertation (University of Helsinki)

2013b. 'Polish-Lithuanian Karaite zemirot: imitation only? A review on a marginal genre' in Travelling through Time: Essays in Honour of Kaj Öhrnberg, ed. Sylvia Akar, Jaakko Hämeen-Anttila, and Inka Nokso-Koivisto (Helsinki, Finnish Oriental Society), pp. 359-79

Walfish, Barry Dov, and Mikhail Kizilov, 20 I r. Bibliographica Karaitica: An Annotated Bibliography of Karaites and Karaism (Leiden and Boston, Brill)

Weinberger, Leon J., I 99 I. Rabbanite and Karaite Liturgical Poetry in South-Eastern Europe. Critical Edition with Introduction and Commentary by Leon J. Weinberger (Cincinnati, Hebrew Union College Press)

— 1998. Jewish Hymnography: A Literary History (London and Portland, OR, The Littman Library of Jewish Civilization)

Yaron, Yoseif, and Avraham Qanaï, 2003. An Introduction to Karaite Judaism: History, Theology, Practice, and Custom (New York, al-Qirqisani Center for the Promotion of Karaite Studies)

Yellin, David, I 972. Törat hash-shìrā has-sěfāradìt (Jerusalem, Magnes Press)

Yeshaya, Joachim, 20 I I. Medieval Hebrew Poetry in Muslim Egypt: The Secular Poetry of the Karaite Poet Moses ben Abraham Dar'i (Leiden and Boston, Brill)

-2014. Poetry and Memory in Karaite Prayer: The Liturgical Poetry of the Karaite Poet Moses ben Abraham Dar'i (Leiden and Boston, Brill) 
‘Ăqēdōt

Zawanowska, Marzena, 201 2. The Arabic Translation and Commentary of Yefet ben 'Eli the Karaite on the Abraham Narratives (Genesis 11:10-25:18) (Leiden, Boston, Brill)

Zunz, Leopold, I 865. Die Literaturgeschichte der Synagogalen Poesie (Berlin, L. Gerschel) 